\title{
Microbacterium profundi sp. nov., isolated from deep-sea sediment of polymetallic nodule environments
}

\author{
Correspondence \\ Xue-Wei Xu \\ xuxw@sio.org.cn
}

\author{
Yue-Hong $\mathrm{Wu},{ }^{1} \mathrm{Min} \mathrm{Wu},{ }^{1}$ Chun-Sheng Wang, ${ }^{2,3}$ Xiao-Gu Wang, ${ }^{2,3}$ \\ Jun-Yi Yang, ${ }^{2,3}$ Aharon Oren ${ }^{4}$ and $\mathrm{Xue}-\mathrm{Wei} \mathrm{Xu}^{1,2,3}$ \\ ${ }^{1}$ College of Life Sciences, Zhejiang University, Hangzhou 310058, PR China \\ ${ }^{2}$ Laboratory of Marine Ecosystem and Biogeochemistry, State Oceanic Administration, Hangzhou \\ 310012, PR China \\ ${ }^{3}$ Second Institute of Oceanography, State Oceanic Administration, Hangzhou 310012, PR China \\ ${ }^{4}$ Institute of Life Sciences and the Moshe Shilo Minerva Center for Marine Biogeochemistry, \\ The Hebrew University of Jerusalem, Jerusalem 91904, Israel
}

Ocean polymetallic nodules form a vast metallic resource on the sea floor. The interesting environment of the deepsea polymetallic nodule regions has only rarely been explored for the presence of novel bacterial species (Liu \& Shao, 2005). Here we present a polyphasic study describing a novel Microbacterium strain isolated from a deep-sea sediment sample collected from a polymetallic nodule area. At the time of writing, the genus Microbacterium, belonging to the family Microbacteriaceae within the class Actinobacteria, contains 49 species of Gram-positive, non-spore-forming, rod-shaped bacteria (Euzéby, 1997; Takeuchi \& Hatano, 1998a). Members of the genus Microbacterium are widespread and can be

The GenBank/EMBL/DDBJ accession number for the 16S rRNA gene sequence of strain Shh49 ${ }^{\top}$ is EF623999.

An extended 16S rRNA gene sequence-based tree, a phenotypic comparison with related type strains and a comparison of fatty acid profiles are available as supplementary material with the online version of this paper. isolated from various habitats, including air, soil, water, milk products and plant, insect and human specimens (Evtushenko \& Takeuchi, 2006).

Deep-sea sediment samples were collected by a multicorer from the East Pacific polymetallic nodule region (station ES0301; $8^{\circ} 22^{\prime} 38^{\prime \prime} \mathrm{N} 145^{\circ} 23^{\prime} 56^{\prime \prime} \mathrm{W}$ ) at a depth of $5280 \mathrm{~m}$ (temperature $2{ }^{\circ} \mathrm{C}$; salinity $34 \%$ ) during cruise DY10512\&14 of the vessel Da Yang Yi Hao in 2003. Aboard ship, sediment samples were subsampled aseptically and stored at $-20{ }^{\circ} \mathrm{C}$ until use.

Approximately $200 \mathrm{mg}$ of the subsample was suspended in $3 \mathrm{ml}$ sterile seawater and vortexed for $15 \mathrm{~min}$. The dispersed sediment suspension was then added to modified ZoBell medium (ZoBell, 1941) and plated by using a tenfold dilution series. The modified ZoBell agar contained ( ${ }^{-1}$ distilled water): $19.45 \mathrm{~g} \mathrm{NaCl}, 8.8 \mathrm{~g} \mathrm{MgCl}_{2}, 3.24 \mathrm{~g}$ $\mathrm{Na}_{2} \mathrm{SO}_{4}, 1.8 \mathrm{~g} \mathrm{CaCl}_{2}, 0.55 \mathrm{~g} \mathrm{KCl}, 0.16 \mathrm{~g} \mathrm{NaHCO}_{3}, 0.1 \mathrm{~g}$ ferric citrate pentahydrate, $80 \mathrm{mg} \mathrm{KBr}, 34 \mathrm{mg} \mathrm{CsCl}_{2}$, $22 \mathrm{mg} \mathrm{H}_{3} \mathrm{BO}_{3}, 4.0 \mathrm{mg} \mathrm{Na} \mathrm{Na}_{2} \mathrm{SiO}_{3}, 2.4 \mathrm{mg} \mathrm{NaF}, 1.6 \mathrm{mg}$ 
$\mathrm{NH}_{4} \mathrm{NO}_{3}, 8.0 \mathrm{mg} \mathrm{Na}_{3} \mathrm{PO}_{4}, 0.5 \mathrm{~g}$ peptone, $0.1 \mathrm{~g}$ yeast extract, $20 \mathrm{~g}$ agar $(\mathrm{pH} 5.5$, adjusted with $\mathrm{HCl}$ ). After 2 weeks of aerobic incubation at $25{ }^{\circ} \mathrm{C}$, a yellow colony, named Shh $49^{\mathrm{T}}$, was picked. The strain was purified by repeated restreaking; purity was confirmed by the uniformity of colony morphology. Unless otherwise stated, strain Shh49 ${ }^{\mathrm{T}}$ was maintained on trypticase soy yeast extract (TSBYE) medium (DSMZ medium 92) at $28{ }^{\circ} \mathrm{C}$.

The optimal conditions for growth were determined in TSBYE medium with different $\mathrm{NaCl}$ concentrations $(0,0.5,1$, $3,5,7.5,10,15,20$ and $30 \%, w / v)$. The $\mathrm{pH}$ range for growth was determined by adding MES ( $\mathrm{pH}$ 5.0-6.0), PIPES ( $\mathrm{pH}$ 6.5-7.0), Tricine ( $\mathrm{pH} 7.5-8.5)$ or CAPSO ( $\mathrm{pH} 9.0$ $10.0)$ to TSBYE medium at a concentration of $25 \mathrm{mM}$. The temperature range for growth was determined by incubating from 4 to $48{ }^{\circ} \mathrm{C}$. Strain Shh $49^{\mathrm{T}}$ could grow at $32{ }^{\circ} \mathrm{C}$ after 2 days and at $35{ }^{\circ} \mathrm{C}$ after 10 days but not at $37^{\circ} \mathrm{C}$ after 10 days. Cell morphology and motility were examined by optical microscopy (Olympus BX40) and electron microscopy (Cambridge S260 and JEM-1230) (Fig. 1).

Single-carbon-source assimilation tests were performed using a minimal medium (Takeuchi \& Hatano, 1998b). Acid production was tested using modified MOF medium supplemented with $0.5 \%$ sugars or alcohols (Leifson, 1963; $\mathrm{Xu}$ et al., 2008). Biochemical tests were performed using the methods described by Mata et al. (2002). API 20NE and API 50CH tests (bioMérieux) were also used to determine physiological and biochemical characteristics. Detailed results are given in the species description.

Fatty acid methyl esters were obtained from cells grown in TSBYE medium for $24 \mathrm{~h}$ at $28{ }^{\circ} \mathrm{C}$ and analysed by using GC/MS (Kuykendall et al., 1988). Isoprenoid quinones were analysed as described previously (Komagata \& Suzuki, 1987) using reversed-phase HPLC, with menaquinones from Microbacterium keratanolyticum DSM $8606^{\mathrm{T}}$ (MK-12 and 13) and Microbacterium phyllosphaerae DSM $13468^{\mathrm{T}}$ (MK-10, 11 and 12) as reference standards. Cell-wall peptidoglycan was prepared and hydrolysed by the methods of Kawamoto et al. (1981) and the amino acid composition was analysed with an automatic amino acid analyser (Hitachi L-8900).

The 16S rRNA gene was amplified as described previously (Xu et al., 2007). Sequence data were aligned with CLUSTAL w 1.8 (Thompson et al., 1994). Phylogenetic trees were constructed by the neighbour-joining (Saitou \& Nei, 1987) and maximum-parsimony (Fitch, 1971) methods with the MEGA 3 program package (Kumar et al., 2004). Evolutionary distances were calculated according to the algorithm of Kimura's two-parameter model (Kimura, 1980) for the neighbour-joining method. The DNA G+C content was determined by thermal denaturation $\left(T_{\mathrm{m}}\right)$ (Marmur \& Doty, 1962) using Escherichia coli K-12 DNA as calibration standard. DNA-DNA hybridizations were performed by the thermal denaturation and renaturation method of De Ley et al. (1970) as modified by Huß et al. (1983), using a Beckman DU 800 spectrophotometer.
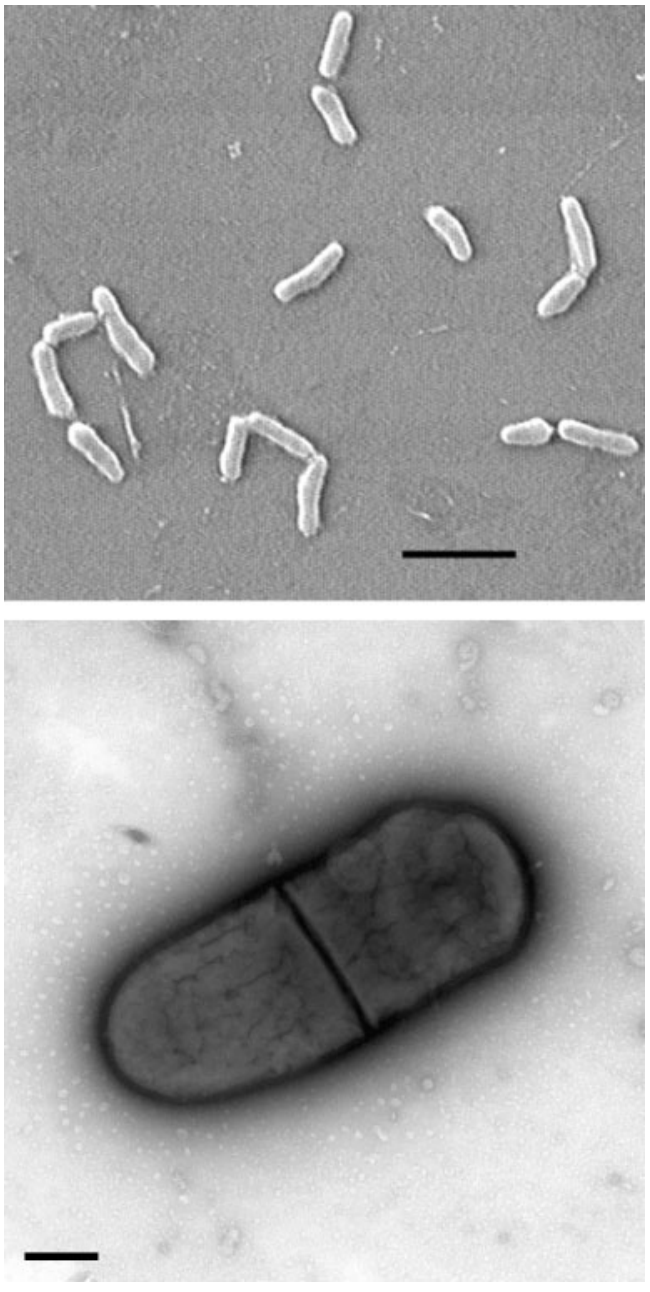

Fig. 1. Scanning electron photomicrograph (top) and transmission electron photomicrograph (bottom) of cells of Microbacterium profundi sp. nov. Shh $49^{\top}$ grown on TSBYE agar. Bars, $2 \mu \mathrm{m}$ (top) and $0.2 \mu \mathrm{m}$ (bottom).

The almost-complete 16S rRNA gene sequence (1488 nt) of strain Shh $49^{\mathrm{T}}$ was compared with closely related sequences of reference organisms from the EzTaxon service (Chun et al., 2007). Strain Shh $49^{\mathrm{T}}$ showed the highest sequence similarity to the type strain of $M$. phyllosphaerae (98.3\%). Phylogenetic analysis based on $16 \mathrm{~S}$ rRNA gene sequence comparison showed that strain Shh $49^{\mathrm{T}}$ formed a coherent cluster with the type strain of M. keratanolyticum (98.0\% sequence similarity) (Fig. 2 and Supplementary Fig. S1, available in IJSEM Online). Comparison of phenotypic properties (Table 1 and Supplementary Tables S1 and S2) indicated differences between strain $\operatorname{Shh} 49^{\mathrm{T}}$ and the other Microbacterium species, such as colony pigmentation, salt or temperature range for growth, $\mathrm{H}_{2} \mathrm{~S}$ formation, hydrolysis of substrates, utilization of hydrocarbons, production of acids from sugars, cell-wall diamino acid composition, menaquinone composition, fatty acids and $\mathrm{G}+\mathrm{C}$ contents. The DNA relatedness values of strain $\operatorname{Shh} 49^{\mathrm{T}}$ to $M$. 


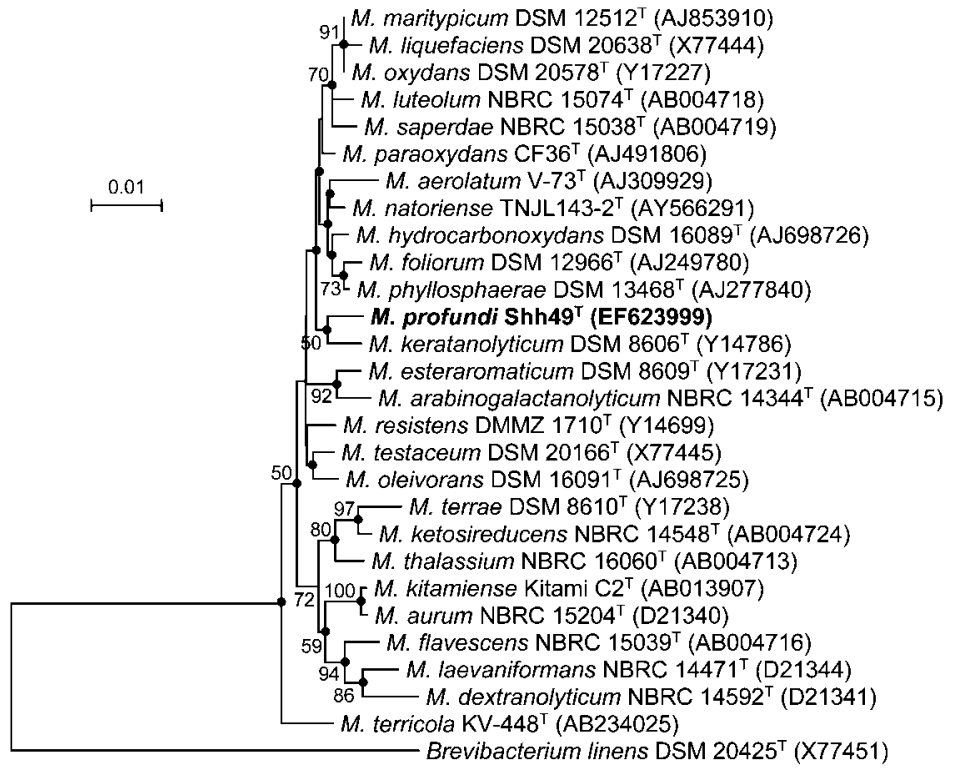

Fig. 2. Neighbour-joining tree based on $16 \mathrm{~S}$ rRNA gene sequences, showing the phylogenetic relationships of the novel isolate and related taxa. Bootstrap percentages are based on 1000 replicates; only values $>50 \%$ are shown. Bar, 0.01 substitutions per nucleotide position. Dots indicate branches of the tree that were also found using the maximumparsimony method. keratanolyticum DSM $8606^{\mathrm{T}}$ and M. phyllosphaerae DSM $13468^{\mathrm{T}}$ were 31 and $56 \%$, respectively.

Therefore, based on the 16S rRNA gene sequence analysis as well as DNA-DNA hybridization data and differential phenotypic properties, we propose that strain Shh $49^{\mathrm{T}}$ represents a novel species within the genus Microbacterium, for which we propose the name Microbacterium profundi sp. nov.

\section{Description of Microbacterium profundi sp. nov.}

Microbacterium profundi (pro.fun'di. L. gen. n. profundi of the depths of the sea, of the deep-sea).

Aerobic and Gram-positive. Spore formation is not observed. Young cultures show short rod-like cells (1.0$2.0 \times 0.4-0.6 \mu \mathrm{m}$ ), occurring singly or in pairs. Colonies are $1-2 \mathrm{~mm}$ in diameter, smooth, circular, elevated and yellow in colour after $48 \mathrm{~h}$ at $28{ }^{\circ} \mathrm{C}$. $\mathrm{NaCl}$ concentration for growth is $0-7.5 \%(\mathrm{w} / \mathrm{v})$, with an optimum at $0-1 \%$. $\mathrm{pH}$ and temperature ranges for growth are $\mathrm{pH} 6.0-9.5$ and $4-35{ }^{\circ} \mathrm{C}$ (optimum at $\mathrm{pH} 7.0-8.0$ and $28^{\circ} \mathrm{C}$ ). Catalasepositive, oxidase-negative. Nitrate is not reduced to nitrite. Aesculin, DNA and gelatin are hydrolysed. Casein, starch, Tweens 20 and 80, tyrosine and urea are not hydrolysed. No growth on MacConkey agar or cetrimide agar. Indole and $\mathrm{H}_{2} \mathrm{~S}$ are not formed. $o$-Nitrophenyl $\beta$-D-galactopyranosidase and selenite reduction are positive. Negative for arginine dihydrolase, $\beta$-galactosidase, lecithinase and gluconate oxidation. Chemo-organotrophic. The following substrates are utilized for growth: acetate, L-arabinose, L-arginine, L-aspartate, cellobiose, D-fructose, fumarate, D-galactose, D-glucose, glycerol, isoleucine, lactate, lactose, lysine, malate, maltose, D-mannitol, D-mannose, propionate, pyruvate, raffinose, rhamnose, ribose, salicin, L-serine, succinate, sucrose, trehalose, L-valine and xylose. The following compounds are not utilized as sole carbon and energy sources: $\mathrm{N}$-acetylglucosamine, adipic acid, L-alanine, capric acid, citrate, L-cysteine, ethanol, formate, glycine, L-histidine, myo-inositol, malonate, L-methionine, potassium gluconate, phenylacetic acid, sorbitol, sorbose and trisodium citrate. According to results from the API $50 \mathrm{CH}$ test, acid is produced from D- and L-arabinose, arbutin, cellobiose, erythritol, aesculin ferric citrate, D-galactose, D-glucose, D-fructose, L-fucose, glycerol, D-lactose, maltose, D-mannitol, $\mathrm{D}$-mannose, methyl $\beta$-D-xylopyranoside, L-rhamnose, Dribose, salicin and D-xylose. Negative for the production of acid from sucrose and trehalose, but positive when tested according to the method of Leifson (1963). Susceptible to ampicillin $(10 \mu \mathrm{g})$, bacitracin $(0.04 \mathrm{IU})$, carbenicillin $(100 \mu \mathrm{g})$, cefalexin $(30 \mu \mathrm{g})$, cefoxitin $(30 \mu \mathrm{g})$, ceftriaxone $(30 \mu \mathrm{g})$, chloramphenicol $(30 \mu \mathrm{g})$, erythromycin $(15 \mu \mathrm{g})$, gentamicin $(10 \mu \mathrm{g})$, minocycline $(30 \mu \mathrm{g})$, neomycin $(30 \mu \mathrm{g})$, novobiocin $(30 \mu \mathrm{g})$, penicillin $(10 \mu \mathrm{g})$, polymyxin $\mathrm{B}$ (300 IU), rifampicin $(5 \mu \mathrm{g})$, streptomycin $(10 \mu \mathrm{g})$ and tetracycline $(30 \mu \mathrm{g})$, but not to kanamycin $(30 \mu \mathrm{g})$, nitrofurantoin $(300 \mu \mathrm{g})$, nystatin $(100 \mu \mathrm{g})$ or tobramycin $(10 \mu \mathrm{g})$. The cell-wall diamino acid is ornithine; alanine, glycine and two unidentified amino acids are also found. The predominant menaquinones are MK-12 and MK-13. Major fatty acids are anteiso- $\mathrm{C}_{15: 0}$, iso- $\mathrm{C}_{15: 0}$, iso- $\mathrm{C}_{16: 0}$ and anteiso$\mathrm{C}_{17: 0}$. The DNA $\mathrm{G}+\mathrm{C}$ content of the type strain is $66.8 \mathrm{~mol} \%\left(T_{\mathrm{m}}\right)$.

The type strain, Shh $49^{\mathrm{T}} \quad\left(=\mathrm{CGMCC} 1.6777^{\mathrm{T}}=\mathrm{JCM}\right.$ $14840^{\mathrm{T}}$ ), was isolated from a deep-sea sediment sample collected from a polymetallic nodule region in the East Pacific Ocean. 
Table 1. Phenotypic characteristics that differentiate strain Shh $49^{\top}$ from related Microbacterium species

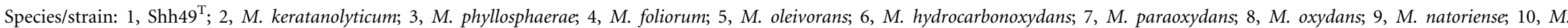

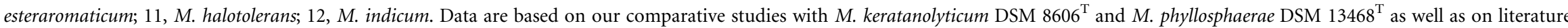

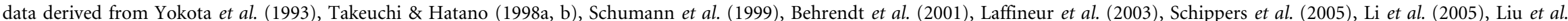
(2005), Evtushenko \& Takeuchi (2006) and Shivaji et al. (2007). +, Positive; (+), weakly positive; -, negative; d, reaction differs among strains; ND, no data available.

\begin{tabular}{|c|c|c|c|c|c|c|c|c|c|c|c|c|}
\hline Characteristic & 1 & 2 & 3 & 4 & 5 & 6 & 7 & 8 & 9 & 10 & 11 & 12 \\
\hline Colony colour ${ }^{\star}$ & Y & Y & Y & Y & $\mathrm{o}$ & Y & LY & Y & Y & $\mathrm{YW} / \mathrm{Y}$ & $\mathrm{w}$ & PY \\
\hline Growth in $6.5 \% \mathrm{NaCl}$ & + & - & ND & ND & - & - & ND & ND & $\mathrm{ND}$ & - & + & ND \\
\hline Growth at $37^{\circ} \mathrm{C}$ & - & - & $\mathrm{d}$ & $\mathrm{d}$ & + & + & + & + & + & $\mathrm{d}$ & + & - \\
\hline $\mathrm{H}_{2} \mathrm{~S}$ production & - & + & - & - & - & - & $\mathrm{ND}$ & + & ND & + & - & ND \\
\hline \multicolumn{13}{|l|}{ Hydrolysis of: } \\
\hline Casein & - & + & + & - & ND & ND & + & ND & - & ND & - & ND \\
\hline Gelatin & + & + & + & + & $\mathrm{ND}$ & $\mathrm{ND}$ & + & + & + & - & - & $\mathrm{ND}$ \\
\hline Starch & - & - & $(+)$ & $(+)$ & ND & $\mathrm{ND}$ & $\mathrm{ND}$ & - & + & + & - & - \\
\hline \multicolumn{13}{|l|}{ Assimilation of: } \\
\hline L-Alanine & - & + & + & ND & - & + & ND & ND & ND & ND & ND & - \\
\hline Arabinose & + & - & + & + & + & + & + & - & + & + & + & + \\
\hline Citrate & - & - & - & $\mathrm{d}$ & - & + & $\mathrm{ND}$ & + & ND & - & ND & - \\
\hline Malate & + & - & + & + & + & + & $\mathrm{ND}$ & + & ND & + & + & ND \\
\hline Propionate & + & + & + & ND & - & + & ND & ND & ND & + & ND & ND \\
\hline Rhamnose & + & - & + & $(+)$ & + & + & + & $\mathrm{ND}$ & - & $\mathrm{ND}$ & - & - \\
\hline \multicolumn{13}{|l|}{ Acid production from: } \\
\hline Glucose & + & - & + & + & - & - & + & + & + & - & + & + \\
\hline Rhamnose & + & - & + & - & - & + & $\mathrm{ND}$ & $\mathrm{d}$ & - & $\mathrm{ND}$ & ND & - \\
\hline Major cellular fatty acids $\dagger$ & $\begin{array}{l}\text { ai15, i15, } \\
\text { i16, ai17 }\end{array}$ & $\begin{array}{l}\text { ai15, i16, } \\
\text { i15, ai17, }\end{array}$ & $\begin{array}{l}\text { ai15, i16 } \\
\text { i15, ai17 }\end{array}$ & $\begin{array}{c}\text { ai15, ai17, } \\
\text { i16 }\end{array}$ & $\mathrm{ND}$ & $\mathrm{ND}$ & $\begin{array}{l}\text { ai15, ai17, } \\
\text { i16, i15, i17 }\end{array}$ & $\begin{array}{l}\text { ai15, ai17, } \\
\text { i16 }\end{array}$ & $\begin{array}{l}\text { ai15, i15, } \\
\text { ai17 }\end{array}$ & $\begin{array}{l}\text { ai15, ai17, } \\
\text { i16 }\end{array}$ & $\begin{array}{l}\text { ai15, ai17, } \\
\text { i16 }\end{array}$ & $\begin{array}{c}\text { i16, ai } 15, \\
16, \text { ail } 17\end{array}$ \\
\hline Menaquinones (MK) & 12,13 & 12,13 & $10,11,12$ & $10,11,12$ & 11,12 & 11,12 & $\mathrm{ND}$ & 11,12 & $9,10,11,12$ & 12,13 & 10,11 & 11,12 \\
\hline Cell-wall diamino acid & Orn & Orn & Orn & Orn & Lys & Orn & Orn & Orn & Orn & Orn & Orn & Orn \\
\hline $\mathrm{G}+\mathrm{C}$ content $(\mathrm{mol} \%)$ & 66.8 & 66.5 & 64 & 67 & $\mathrm{ND}$ & ND & 69.9 & 67 & 69.1 & 68.8 & 63.8 & 65.5 \\
\hline
\end{tabular}

${ }^{*}$ LY, Lemon yellow; O, orange; PY, pale yellow; w, white; Y, yellow; YW, yellow-white

†ai, Anteiso-branched acid; i, iso-branched acid. 


\section{Acknowledgements}

This work was supported by grants from the Major State Basic Research Development Program of China (973 Program) (2004CB719604-3), the China Ocean Mineral Resources R \& D Association (COMRA) Special Foundation (DYXM-115-01-3-01, DYXM-115-01-3-02) and the Scientific Research Fund of the Second Institute of Oceanography, SOA (JT0709).

\section{References}

Behrendt, U., Ulrich, A. \& Schumann, P. (2001). Description of Microbacterium foliorum sp. nov. and Microbacterium phyllosphaerae sp. nov., isolated from the phyllosphere of grasses and the surface litter after mulching the sward, and reclassification of Aureobacterium resistens (Funke et al. 1998) as Microbacterium resistens comb. nov. Int J Syst Evol Microbiol 51, 1267-1276.

Chun, J., Lee, J. H., Jung, Y., Kim, M., Kim, S., Kim, B. K. \& Lim, Y. W. (2007). EzTaxon: a web-based tool for the identification of prokaryotes based on 16S ribosomal RNA gene sequences. Int J Syst Evol Microbiol 57, 2259-2261.

De Ley, J., Cattoir, H. \& Reynaerts, A. (1970). The quantitative measurement of DNA hybridization from renaturation rates. Eur $J$ Biochem 12, 133-142.

Euzéby, J. P. (1997). List of Bacterial Names with Standing in Nomenclature: a folder available on the Internet. Int J Syst Bacteriol 47, 590-592. http://www.bacterio.cict.fr

Evtushenko, L. I. \& Takeuchi, M. (2006). The family Microbacteriaceae. In The Prokaryotes: a Handbook on the Biology of Bacteria, 3rd edn, vol. 3, pp. 1020-1098. Edited by M. Dworkin, S. Falkow, E. Rosenberg, K. H. Schleifer \& E. Stackebrandt. New York: Springer.

Fitch, W. M. (1971). Toward defining the course of evolution: minimum change for a specific tree topology. Syst Zool 20, 406-416.

Huß, V. A. R., Festl, H. \& Schleifer, K. H. (1983). Studies on the spectrophotometric determination of DNA hybridization from renaturation rates. Syst Appl Microbiol 4, 184-192.

Kawamoto, I., Oka, T. \& Nara, T. (1981). Cell wall composition of Micromonospora olivoasterospora, Micromonospora sagamiensis, and related organisms. J Bacteriol 146, 527-534.

Kimura, M. (1980). A simple method for estimating evolutionary rates of base substitutions through comparative studies of nucleotide sequences. J Mol Evol 16, 111-120.

Komagata, K. \& Suzuki, K. (1987). Lipid and cell-wall analysis in bacterial systematics. Methods Microbiol 19, 161-207.

Kumar, S., Tamura, K. \& Nei, M. (2004). MEGA3: integrated software for molecular evolutionary genetics analysis and sequence alignment. Brief Bioinform 5, 150-163.

Kuykendall, L. D., Roy, M. A., O'Neill, J. J. \& Devine, T. E. (1988). Fatty acids, antibiotic resistance, and deoxyribonucleic acid homology groups of Bradyrhizobium japonicum. Int J Syst Bacteriol 38, 358-361.

Laffineur, K., Avesani, V., Cornu, G., Charlier, J., Janssens, M., Wauters, G. \& Delmee, M. (2003). Bacteremia due to a novel Microbacterium species in a patient with leukemia and description of Microbacterium paraoxydans sp. nov. J Clin Microbiol 41, 2242-2246.

Leifson, E. (1963). Determination of carbohydrate metabolism of marine bacteria. J Bacteriol 85, 1183-1184.
Li, W.-J., Chen, H.-H., Kim, C.-J., Park, D.-J., Tang, S.-K., Lee, J.-C., Xu, L.-H. \& Jiang, C.-L. (2005). Microbacterium halotolerans sp. nov., isolated from a saline soil in the west of China. Int J Syst Evol Microbiol 55, 67-70.

Liu, C. \& Shao, Z. (2005). Alcanivorax dieselolei sp. nov., a novel alkane-degrading bacterium isolated from sea water and deep-sea sediment. Int J Syst Evol Microbiol 55, 1181-1186.

Liu, J., Nakayama, T., Hemmi, H., Asano, Y., Tsuruoka, N., Shimomura, K., Nishijima, M. \& Nishino, T. (2005). Microbacterium natoriense sp. nov., a novel D-aminoacylase-producing bacterium isolated from soil in Natori, Japan. Int J Syst Evol Microbiol 55, 661-665.

Marmur, J. \& Doty, P. (1962). Determination of the base composition of deoxyribonucleic acid from its thermal denaturation temperature. J Mol Biol 5, 109-118.

Mata, J. A., Martinez-Canovas, J., Quesada, E. \& Bejar, V. (2002). A detailed phenotypic characterisation of the type strains of Halomonas species. Syst Appl Microbiol 25, 360-375.

Saitou, N. \& Nei, M. (1987). The neighbor-joining method: a new method for reconstructing phylogenetic trees. Mol Biol Evol 4, 406-425.

Schippers, A., Bosecker, K., Spröer, C. \& Schumann, P. (2005). Microbacterium oleivorans sp. nov. and Microbacterium hydrocarbonoxydans sp. nov., novel crude-oil-degrading Gram-positive bacteria. Int J Syst Evol Microbiol 55, 655-660.

Schumann, P., Rainey, F. A., Burghardt, J., Stackebrandt, E. \& Weiss, N. (1999). Reclassification of Brevibacterium oxydans (Chatelain and Second 1966) as Microbacterium oxydans comb. nov. Int J Syst Bacteriol 49, 175-177.

Shivaji, S., Bhadra, B., Rao, R. S., Chaturvedi, P., Pindi, P. K. \& Raghukumar, C. (2007). Microbacterium indicum sp. nov., isolated from a deep-sea sediment sample from the Chagos Trench, Indian Ocean. Int J Syst Evol Microbiol 57, 1819-1822.

Takeuchi, M. \& Hatano, K. (1998a). Union of the genera Microbacterium Orla-Jensen and Aureobacterium Collins et al. in a redefined genus Microbacterium. Int J Syst Bacteriol 48, 739-747.

Takeuchi, M. \& Hatano, K. (1998b). Proposal of six new species in the genus Microbacterium and transfer of Flavobacterium marinotypicum ZoBell and Upham to the genus Microbacterium as Microbacterium maritypicum comb. nov. Int J Syst Bacteriol 48, 973-982.

Thompson, J. D., Higgins, D. G. \& Gibson, T. J. (1994). CLUSTAL W: improving the sensitivity of progressive multiple sequence alignment through sequence weighting, position-specific gap penalties and weight matrix choice. Nucleic Acids Res 22, 4673-4680.

Xu, X.-W., Wu, Y.-H., Zhou, Z., Wang, C.-S., Zhou, Y.-G., Zhang, H.-B., Wang, Y. \& Wu, M. (2007). Halomonas saccharevitans sp. nov., Halomonas arcis sp. nov. and Halomonas subterranea sp. nov., halophilic bacteria isolated from hypersaline environments of China. Int J Syst Evol Microbiol 57, 1619-1624.

Xu, X.-W., Wu, Y.-H., Wang, C.-S., Yang, J.-Y., Oren, A. \& Wu, M. (2008). Marinobacter pelagius sp. nov., a moderately halophilic bacterium. Int J Syst Evol Microbiol 58, 637-640.

Yokota, A., Takeuchi, M., Sakane, T. \& Weiss, N. (1993). Proposal of six new species in the genus Aureobacterium and transfer of Flavobacterium esteraromaticum Omelianski to the genus Aureobacterium as Aureobacterium esteraromaticum comb. nov. Int J Syst Bacteriol 43, 555-564.

ZoBell, C. E. (1941). Studies on marine bacteria. I. The cultural requirements of heterotrophic aerobes. J Mar Res 4, 42-75. 